\title{
Qualifications and Certificates v Practical Knowledge and Experience: Is There a Winner?
}

\author{
Eddie Fisher (Corresponding author) \\ Faculty of Social Sciences, Universidad de Oriente, Santiago de Cuba, Cuba \\ 8 Kendal, Swindon, Wiltshire, SN5 8HW, United Kingdom \\ Tel: 44-179-349-0423 E-mail: eddie.fisher9@btinternet.com \\ Yorkys Santana González \\ Faculty of Social Sciences, Universidad de Oriente, Santiago de Cuba, Cuba
}

\author{
Received: February 25, 2020 Accepted: March 15, 2020 Published: March 23, 2020 \\ doi:10.5296/ber.v10i2.16520ＵRL: https://doi.org/10.5296/ber.v10i2.16520
}

\begin{abstract}
There appears to be a continuing and inconclusive debate amongst scholars whether theoretical knowledge or practical experience is more important in related and associated areas such as education, recruitment and employability. This research, limited to a literature review and face to face interviews, conducted a systematic investigation to obtain and analyze valid and reliable research data to establish whether theoretical knowledge or practical experience are of paramount importance. The outcome of this research suggests that a hybrid approach should be adopted, with the major focus being on practical experience supported by relevant theoretical knowledge and not the converse. A number of additional recommendations are presented how to balance and close the gap between theory and practice including a redesign of ordinary and advanced level educational teaching. Far greater emphasis needs to be placed on young people gaining early practical experience inside and outside the classroom. This can be achieved by developing practical workshops (pilot studies) for use in safe laboratory-type environments and by extending work placements within organizations during term times.
\end{abstract}

Keywords: Qualifications, Practical Knowledge, Theoretical Understanding, Education, Recruitment, Employability 


\section{Introduction}

\subsection{Introduction}

'The only source of knowledge is experience' (Albert Einstein).

'An investment in knowledge pays the best interest' (Benjamin Franklin)

The continuing gap between theoretical knowledge and practical experience in the areas of education, recruitment and employability of people has become a major concern for educational establishments, employers and the recruitment industry. There is room for both theory and practice and it appears that the optimum situation is when both co-exist. In contrast, there are situations when practical knowledge is of greater importance than theoretical knowledge, for example, in teaching and engineering. It should also be taken into account that practical applications are generally based on prior theoretical knowledge. This research is considered urgent to investigate and report whether this gap continues to exist between theoretical and practical applications within the limitations of this research such as education, recruitment and employability, to provide recommendations how this gap could be closed and propose and report how effective applications of the research outcomes could bring theory and practice closer together. New approaches and innovative thinking are now deemed necessary to develop new considerations whether certificates/qualifications or knowledge/experience are of paramount importance. This will allow practitioners and academics to adopt new insights from this research and improve/update existing models/approaches for the particular benefit of the community of practice. In addition, the research outcome will provide suggestions how existing overqualification situations in countries such as Spain can be overcome through the adoption of new approaches to combat these current shortfalls, including related cost reductions in retaining and recruiting talent into organizations. For example, a survey conducted by Oxford Economics in the United Kingdom during 2014 reveals that the average true cost of replacing members of staff costs employers on average $£ 31,000$. This includes costs for loss of output whilst replacement staff 'get up to speed' and the logistical cost of recruiting and absorbing a new employee. It appears that people joining from the same sector reach optimum productivity in around 15 weeks, those who join from other sectors need 32 weeks to reach this level. New graduates require 40 weeks to achieve the same. Employers, Educational Institutions and Recruitment Agencies need to play a major and more engaged role to get and keep potential job candidates at optimum performance levels to support organizations to replace job leavers and to recruit into new vacancies at optimum cost level. Candidates need to shift from theory to practice to knowledge/experience at a much faster pace to become fully integrated/efficient much faster. There appears to be a paradigm shift from having 'letters behind names and degrees' to practical experience. Gone are the days of 'jobs for life'. So-called career portfolios (visual representation of abilities, skills, capabilities, knowledge, qualities and one's potential) appear to be the new and latest trend. The recruitment market has responded appropriately. Knowledge, experience and qualifications can no longer be considered in isolation. This research has adopted the following interpretations of what is meant by Apprenticeship, Qualifications and Examination in the context of this research: 
Apprenticeship: is a way of gaining the skills, knowledge and experience people need to get into many careers. This includes work, training and study (www.ucas.com)

Qualification: is a normally certificated endorsement, from a recognised awarding body, that a level or quality of accomplishment has been achieved by an individual. Qualifications are usually conferred on successful completion of an examination although not all examinations necessarily offer qualifications (British Qualifications, 2019)

Examination: is a formal test or assessment. It can focus on knowledge, understanding, skill or competence (British Qualifications, 2019)

A literature review is presented next, followed by the main research questions for this research. The outputs from face to face interviews with a large group of undergraduate students of psychology/social psychology from the Universidad José Eduardo Dos Santos, Escola Superior Polítecnica do Bié, Angola are presented next. The research methodology, research results and a discussion of the findings follow. And, finally, the conclusions drawn from this research are presented in the Conclusions section. This includes the research's limitations, suggestions for future research and whether the main research questions (Section 1.3) have been answered.

\subsection{Literature Review}

\subsubsection{Qualifications/Certificates and Practical Experience}

According to OECD (2000), a higher demand for skills has been driving changes in young people's attitudes towards specific preparation for working life. OECD claim that young people are now more likely to combine studying and working. Education systems across the world appear to be encouraging this blend of theoretical knowledge and practical experience. The result is a much smoother transition from transition from education to full-time work. OECD argues that 'No one pathway-whether apprenticeship, school-based vocational or general education-appears to hold the key to successful transition outcomes' (p.15). Workplace experience is considered important when combined with education such as matching employers and young people better, improving the quality of leaving and developing important work-related knowledge and skills. Other approaches to align workplace experience with education are apprenticeships, co-operative education (school-organised workplace experience) and the integration of workplace into school programmes. Young people's transition from education to work is of paramount experience to ensure that they do not have to compete for work unprepared.

The British Qualifications Guide (2019) reports that major technological developments and advances have allowed for more flexible and dynamic delivery of types of learning options. This has enabled education at all levels and by all social classes within the population. The subject matter range on offer has widened tremendously, partially based on new areas of research being available. It appears that potential employers and professional education bodies have been working together to develop new subject areas that are aligned to the forever-changing industry requirements. The resulting higher levels of choice and flexibility to acquire new knowledge and recognised qualifications/certificates has made it possible to 
bring theory and practice much closer together. The two concepts of practice and learning have been brought together much more closely thanks to the introduction of extended industry and professional placements. This includes the return of so-called 'Apprenticeships'. Miller et al. (1991) almost thirty years ago, suggest that the substantial increase in work experience can be seen as a wider movement to reintegrate education and work. In the past, work appeared to have been integrated into the lives of people, with particular emphasis on family life in the household. Within this family unit, distinctions between work, education and other aspects of social and economic life were mainly absent. Families used to pass down skills, knowledge and attitudes necessary for the household to exist as a unit that functioned. Following industrialisation, work became more and more separated from the household. It became very distinct from it. Education became preserved in formal schools, and this became separated from the family and the world of work (Jamieson and Miller, 1991, Chapter 1). From a job-hunting perspective, Aspire Personnel (2019) report that it appears that qualifications and 'letters behind one's name' are no longer considered to be the drivers to get people on their career ladder. Many people today favour work experience over a costly degree. In addition, employers suggest that students are not ready for the workplace. Aspire Personnel consider the following advantages of both qualifications and experience (Table 1). Ideal is a good combination of both theoretical knowledge and practical understanding. Different industries will favour either or both. Neither of these attributes is more important. There are many successful people with and without degrees.

Table 1. Advantages of qualifications and experience (Aspire Personnel, 2019)

\begin{tabular}{|l|l|}
\hline Qualifications & Experience \\
\hline $\begin{array}{l}\text { Intellectual, social and personal } \\
\text { development of the individual }\end{array}$ & $\begin{array}{l}\text { Three years solid experience combined with } \\
\text { some relevant industry qualifications. Experience } \\
\text { means immediate work engagement }\end{array}$ \\
\hline $\begin{array}{l}\text { Businesses value degrees and this is } \\
\text { reflected in their job advertisements }\end{array}$ & $\begin{array}{l}\text { Employers have become more focused on work } \\
\text { experience }\end{array}$ \\
\hline $\begin{array}{l}\text { Greater focus on intellectual rather than } \\
\text { manual skills }\end{array}$ & $\begin{array}{l}\text { Practical experience provides a true } \\
\text { understanding how companies function and } \\
\text { operate }\end{array}$ \\
\hline $\begin{array}{l}\text { New 'sandwich' degree focus on in-depth } \\
\text { learning combined with hands-on } \\
\text { experience, with a strong focus on the } \\
\text { application of associated knowledge }\end{array}$ & $\begin{array}{l}\text { Experience provides evidence of good team } \\
\text { working, working well under pressure, being } \\
\text { punctual and loyal and having an ability to adapt } \\
\text { and achieve in real-life working environments }\end{array}$ \\
\hline
\end{tabular}

Williams (2018) argues that experience, based on what people have actually done, is of paramount importance. This should include challenges people faced and how they lived up to those. Developed skills sets from an integral part of this approach. Williams continues that attitude, behaviour and personal qualities outweigh qualifications, skills or experience. A highly employable job candidate, for example, is someone who can show that they are a team player and will make significant contributions to the organisation they are going to work for. 


\section{MInstitute ${ }^{\text {Mech }}$}

Business and Economic Research

ISSN 2162-4860

2020, Vol. 10, No. 1

There are four personal attributes that appear to be more important than qualifications and experience: contribution, cultural fit, motivation and engagement. These are the things that can make a business successful. Companies who employ people with these attributes, are most likely to be dynamic, fast and flexible, and respond well to change. Of equal importance are personal qualities such as likeability and adaptability. Williams suggests that personal qualities similar to personal attributes, are the building blocks of professionalism. Qualifications and certificates are important but not as important as personal qualities and attributes. It is necessary to distinguish and differentiate between skills acquired through training and skills gained through experience. Both are not mutually exclusive. In addition, transferable abilities such as problem solving and drive/determination, are considered to be highly desirable skills that far outweigh qualifications and certificates.

Watts (1991) argues that the phrase 'work experience' is a paradoxical phrase. It is clearly distinguished from 'work' and is applied to desirable schemes that only partially cover the work experience. Participants in the scheme experience the tasks associated with the work but do not experience 'being' a full-time worker Young people on a work-experience scheme are not employees but considered to be learners. The learning outcome will only be substantial provided that participants are engaged closely in work. This means as closely as 'being' an employee. Another paradox. Watts suggests that work experience schemes can be dubious in character whereas others are highly respectable. Based on the outcome of some research, at national, local and school level, it is suggested that possible aims of work experience can be grouped together under 10 categories (Table 2). This includes to help students to learn and apply learned skills (enhancing) and be better prepared for the transition from classroom to work environments (anticipatory).

Table 2. Possible aims of work experience, adapted from Watts (1991)

\begin{tabular}{|l|l|}
\hline Enhancing & Apply learned skills in work environments \\
\hline Motivational & Align school curriculum with levels of academic achievements \\
\hline Maturational & Improve social and personal development \\
\hline Investigative & Brings knowledge and understanding of work closer together \\
\hline Expansive & Widest range of occupations \\
\hline Sampling & Try and test vocational preferences \\
\hline Preparatory & Matching skills and knowledge with considered work areas \\
\hline Anticipatory & Manage transition from classroom to work better \\
\hline Placing & Strengthen relationships with employers \\
\hline Custodial & Temporary transfer of responsibilities to students/learners \\
\hline
\end{tabular}

In contrast, and according to Garcia-Mainar and Montuenga (2019), over-education appears to be a rising problem, for example, in Spain. Individuals decide to obtain as many qualifications as possible so that they can compensate for certain other skills they do not have or in order to gain access to the labor market. Spain has a high level of unemployment and large numbers of overqualified people. Garcia-Mainar and Montuenga quote McGuinness and Sloane (2011) who suggest that over-education is considered to be sub-optimal. This is 
due to search or job frictions and pressure from peer groups who hold an equal number of similar qualifications. This appears to drive the desire to have more qualifications than others to gain a competitive advantage in the labor market. Less experienced and less-able workers try to signal to potential employers that they are equally qualified to do jobs they applied for. It makes up for the lack of other skills and to disguise themselves from other candidates who are better able and qualified to do the job. The outcome of research conducted by Garcia-Mainar and Montuenga suggests that over-educated people are less job-satisfied and more inclined to search for another job. It appears that these people prefer to have a job that better matches their abilities, skills and qualifications at the work level. In general, workers acquire more than productive education. An improved understanding of the impact over-qualification has on the labor market has led to suggestions that some policies in the labor market functioning and the education system should be looked at again. In addition, Koval et al. (2016) report that updating any vocational training system to improve educational processes, requires a constant monitoring of the employer's satisfaction with the educational services quality. South Ural State University in Russia has developed a method for monitoring employer's satisfaction with the quality of students and graduates as far as qualifications are concerned. This method is based on a competence-based approach that includes the following:

- Determining the criteria for developing the universal set of students

- Making a list of competences and adjusting it with employers

- Asking students and graduates to take part in assessing regularly 'certainty requirements'

Competences are assessed against the following criteria:

- Motivation to perform

- Computer literacy

- Designing of technical documentation

- Designing work

- Collaborating with others

- Decision-making and working independently

- Adjusting and servicing equipment

- Innovative working to improve engineering solutions

The outcome of this research suggests that the above-mentioned competences, in terms of importance and skills, play an important role in aligning young people's abilities and skills with the performance satisfaction expectations of employers. This is particularly true to say for the transition from education to starting work. 


\subsubsection{Employability and Knowledge}

Rook (2013) quotes Hillage and Pollard (1998) who define employability as 'the capability to move sufficiently within the labor market to realise potential through sustainable employment. For the individual, employability depends on the knowledge, skills and attitudes they possess, the way they use those assets and present them to employers' (page 8). Employability is made up of three vital qualities: Knowledge, Commitment and Skills. These qualities can be developed, over time, through experience and qualifications. All three are easily transferable between jobs. It is suggested that both technical competencies and transferable abilities are needed (technical are job specific and transferable can be applied in a range of fields). Rook considers that common transferable skills required by employers are (not in order of any priority): Enthusiasm and Self-reliance, Numeracy, IT, Teamwork, Research, Organisation, Leadership, Management, Creativity, Problem-solving, Commercial Awareness and Customer Service. Rook reports that only 30-40\% of graduates take up employment/start their careers in subject matters directly related to their degrees. It appears that grades and skills are better indicators of people's potential than their knowledge. Recent research suggests that those with certificates and qualifications still earn more over their careers than those without. There appears to be a trend that most recruiters hire people with qualifications during the penultimate year of study (optimum balance between theoretical and practical work experience). Rook argues that experience is central to any employment process. It helps people to confirm their chosen career decisions, prove their skills and identify their particular strengths. All experience is beneficial irrespective of whether this is relevant to any chosen profession. People's own transferable skills can be developed independent of this. Relevant experience appears to be paramount to achieving any chosen career and those with qualifications/certification can develop their careers incrementally much faster:

Step 1: Take up voluntary or casual work and sign up for any career-related modules at University or night course study levels

Step 2: Focus on activities at part time/full time work that demonstrates the skills needed for the chosen career, and start to network

Step 3: Get relevant jobs that are closely aligned to the chosen career, shadow contacts and get some highly relevant employment advice

Step 4: Find an internment and continue to build networks

Rook argues that networking is essential to a successful career irrespective of relevant qualifications or certifications. It is about getting to know like-minded people with whom they can build long-standing friendships and business relationships. It involves contacting others and providing mutual support and getting to know the people who they know. This provides huge opportunities to create solid networks across a range of business industries. It is a two-way process and needs to offer mutual help and support for this to work effectively. In summary, Rook suggests that employers, generally, are ore concerned with grades, skills and employment experience than what people actually know. The basis of most selection criteria are skills, commitment and knowledge (Fig.1). Job candidates are assessed against 
these selection criteria.

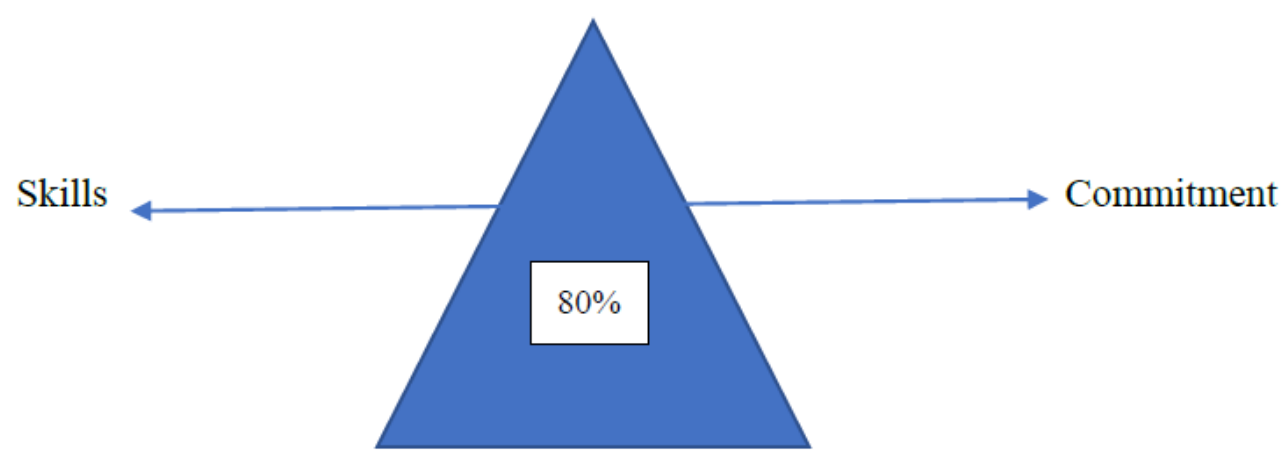

Knowledge

Figure 1. The basis of most selection criteria

Trought (2012) quotes Mike Hill (CEO, Higher Education Services) who suggests that so-called portfolio careers appear to have replaced job-for-life notions of previous years. People do not stay long enough with any single employer and they tend to change job types, too, such as being a journalist one minute and becoming self-employed the next in the area of IT, for example. People's basic employability became the building block upon which the next job/future career could be built. Employability does not require any formal qualification. Desired attributes are being industrious, hard-working, reliable and conscientious. Effective communications, the ability to gather, analyse and evaluate information and continuous personal development (CPD) are inherent skills, too. Formal qualifications are often necessary but are rarely sufficient. Employability can be learned. Trought argues that is up to individuals to market their employability to convince potential employers. Focus should be on selling skills sets in support of any qualification such as a degree. There appears to be a strong correlation between high levels of employability and people's qualifications/personal/interpersonal skills sets. People with combinations of qualifications and skills such as effective communications, team-working and problem-solving have distinct advantages securing a new job or career move:' In many cases a degree is merely the passport for entry; it is the demonstration of employability skills that is used to differentiate candidates' (page 3). It is the students' ability to develop employability skills that is of paramount importance to differentiate them from the competition.

Lumley and Wilkinson (2014) refer to employability assets as being a mix of skills, knowledge, experience, attitudes and mindset. Academic success can show evidence of employability assets such as important transferable skills that include an ability to conduct research, analyse problems as well as organisational and self-management skills. In addition, certain aspects of people's mindset such as being relentless, determined and having high levels of self-confidence. There appears to be another issue in today's ever-changing business and employment market. Many employers are not just looking for good academic results. They are looking for people with excellent transferable skills and those who possess a special mindset, including evidence of engaging in extra-curricular activities. Qualifications and 


\section{Macrothink}

Business and Economic Research

ISSN 2162-4860

2020, Vol. 10, No. 1

Certificates are no longer of absolute and paramount importance. Lumley and Wilkinson suggest that these personal qualities and attitudes are now believed to be crucial, too, for employability. They quote Yorke (2006, page 8 ) who claims that employability can be defined as 'a set of achievements-skills, understanding and personal attributes-that makes graduates more likely to gain employment and be successful in their chosen occupations, which benefits themselves, the workforce, the community and the economy'. In contrast, Hillage and Pollard (1998) suggest that knowledge, skills and attitudes, on their own, are not sufficient to impress potential employers. It is a necessary requirement to present these effectively to employers such as providing employers with evidence of what people have done by demonstrating that they possess these skills. Pool and Sewell (2007, cited in Sewell and Dacre Pool, 2010) present a model of employability that is based on a combination of reflection and evaluation (theoretical and practical experiences) and personal self-evaluation such as self-efficacy, self-esteem and self-confidence (Fig.2).

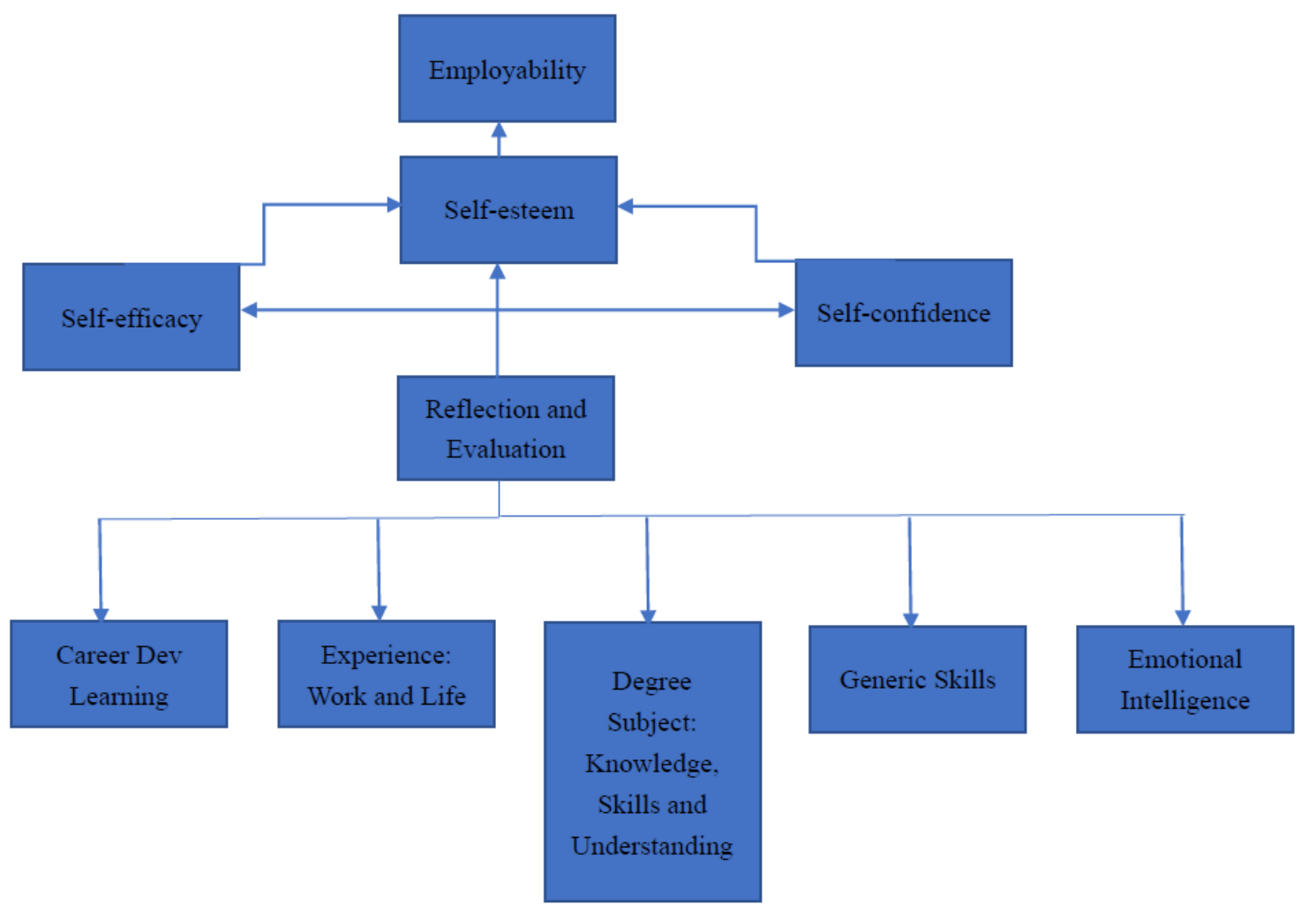

Figure 2. The Career Model (Sewell and Dacre Pool, 2010)

Lumley and Wilkinson argue that qualifications and certifications, on their own, are not adequate to secure a job or career. It is the quality of these qualifications/certifications that matter. People should endeavour to get the best possible pass marks. In addition, they should focus on having a clear understanding what employers are actually looking for in job candidates. For example, research conducted by Woodman and Hutchings (2011) on behalf of the Chartered Management Institute (CMI) suggests the following factors (Table 3) with the 
biggest impact on recruitment decisions about young people (in order of priority):

Table 3. Chartered Management Institute's biggest recruitment impact Factors-young people (2011)

\begin{tabular}{|l|l|l|}
\hline Factors & Skills & Mindset \\
\hline Personal Presentation & Communication & Attitude and ambition \\
\hline Academic Qualification & Planning and organising & $\begin{array}{l}\text { Workplace skills } \\
\text { (such as communications) }\end{array}$ \\
\hline Ambition & Customer Service & Discipline and punctuality \\
\hline $\begin{array}{l}\text { Wider 'non-professional' } \\
\text { experience }\end{array}$ & Decision-making & Levels of literacy \\
\hline Vocational Qualifications & Quality control & Levels of numeracy \\
\hline Knowledge of industry sector & Team leading & Level of commercial awareness \\
\hline References & Performance monitoring & Decision-making abilities \\
\hline Knowledge of the organisation & Resource Management & Technical skills \\
\hline & & Turnover \\
\hline
\end{tabular}

In addition, learning/work experiences play an important part in people's lives. Work experience forms an important part of how people learn and grow. Hooley and Grant quote Kolb (1984) who developed a learning cycle (Fig. 3) claiming that people learn from experiences. This model focuses on how individuals learn from their direct experiences. The cycle divides learning into four well-defined stages:

1. Concrete experience-when people do things

2. Reflection and Observation-when people think about how an experience went

3. Abstraction and Conceptualisation-when people think about what the experiences actually mean and consider what impact this could have on how they look at things now and in future

4. Active experimentation-when people apply some of the new ideas to their experience According to the model, without experiences (Stage 1) all the other stages do not make any sense. 


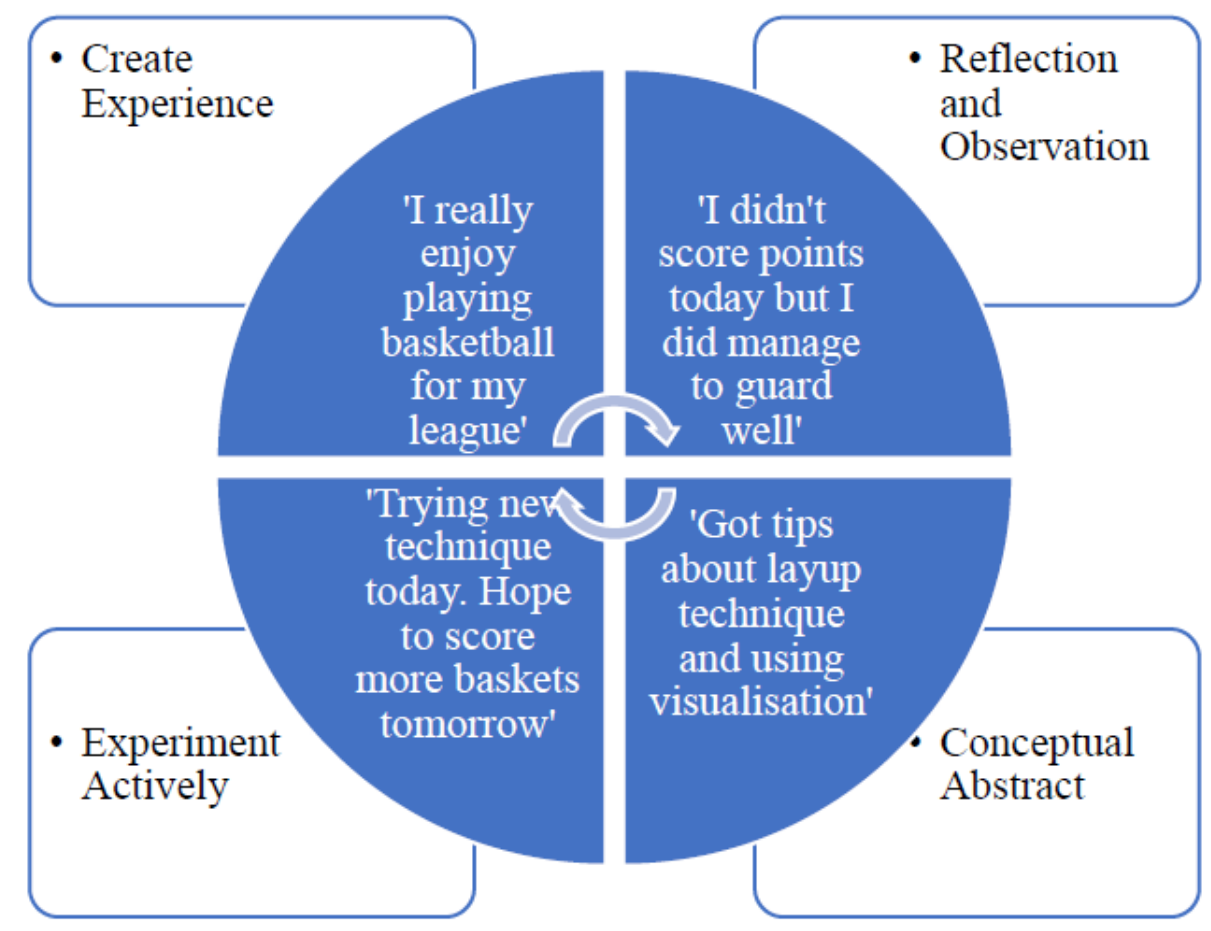

Figure 3. Kolb's Learning Cycle (1984)

Becker and Becker (2016) report that employability appears to be the most important factor. Until people understand how employable they really are, it appears that they cannot move forward as far as career planning is concerned. It is imperative that people offer a good fit between who they are and what they stand for, and the roles they are fulfilling. People need to clearly know themselves in the context of their career development. Becker and Becker suggest that in addition to experience and qualifications, it is important that people formulate which roles best suit them. This should include, for example, part-time jobs and voluntary job experiences as these, too, can prove people's employability and transferable skills. Experience In addition, potential employees are looking for evidence how people's practical experience can benefit the organisation. Becker and Becker argue that employers, generally, care most about the totality of what people have to offer. This includes qualifications, experience, skills, achievements and personal qualities. Fitting the role profile is also of paramount importance. In this context, Becker and Becker refer to qualifications as any formal qualifications from school, college or University as well as relevant courses completed in education or the workplace (Table 4, not in order of priority). In addition, personal qualities matter. It is what allows people to use the skills they possess. For example, a customer care representative needs to have patience. A competency in this context is defined as bringing together a skill and a quality. A skill is defined in the Concise Oxford Dictionary (2011) as 'expertness, practised ability, facility in doing something, dexterity, tact'. Employers want the right person for the right job. This person may not necessarily have all the right qualifications and experiences for the job. It explains why many employers conduct aptitude and psychometric tests to establish the fit of potential job candidates. 
Table 4. Skills, Qualifications, Experience and Personal Qualities, adapted from Becker and Becker (2016), Trought (2012) and Williams (2018)

\begin{tabular}{|c|c|c|c|c|}
\hline $\begin{array}{l}\text { Abilities/Transferable } \\
\text { Abilities }\end{array}$ & Skills & Qualifications & $\begin{array}{l}\text { Personal } \\
\text { Qualities/Attributes }\end{array}$ & $\begin{array}{l}\text { Experience/ } \\
\text { Knowledge }\end{array}$ \\
\hline Decision-making & Leadership & ' $\mathrm{O}$ ' and 'A' Levels & Self-evaluation & Reflections \\
\hline Attitude and Ambition & Team-working & Degrees such as & Self-efficacy & Evaluations \\
\hline Discipline & Commercial & BA, MA and DBA & Self-esteem & Theoretical and \\
\hline Punctuality & Awareness & Apprenticeships & Self-confidence & Practical \\
\hline Technical Abilities & Problem-solving & Work Experience & Emotional & Experiences \\
\hline Aspiration & Communications & Distance Learning & Intelligence & \\
\hline Operativity & Numeracy & Online & Personal Presentation & \\
\hline Emotional Intelligence & Creativity & Certifications & Wider & \\
\hline \multirow[t]{4}{*}{ Critical Thinking } & Operativity & Sandwich Courses & non-professional & \\
\hline & Enthusiasm & Virtual & experience & \\
\hline & Self-reliance & (VR) Learning & Industry Sector & \\
\hline & & & Knowledge & \\
\hline
\end{tabular}

Rook (2016) reports that people have a plethora of career options in today's ever-changing and demanding career market. People need to take control of their destiny as far as employability is concerned. This includes developing the skills considered a necessary requirement by some employers. In addition, some work experience is highly desirable as some employers consider this to be a 'try before you buy' opportunity to assess how well candidates will fit the corporate culture of the organisation. Rook points out that 'You get out what you put in' (page 3). Rook defines experience as 'Employment experience is any paid or unpaid activity which helps you develop your employment-related skills' (page 5). Employability appears to be the key to a successful and long career. It is made up of skills, commitment and knowledge. They underpin people's abilities to succeed at work. Experience has grown in importance and it is now a matter of developing the skills needed to undertake a certain job through personal experience. It is experience that is crucial to employability. Academic knowledge appears to be no longer of paramount importance and sufficient on its own to guarantee a successful career. Rook suggests that a combination of academic qualifications/certificates, knowledge, skills and experience is the optimum combination to develop a successful long-term career. It should also be noted that the outcome of some recent research carried out by Reed for Timebank established that $73 \%$ of employers prefer candidates with volunteering experience, $94 \%$ are confident that volunteering adds to skills and $58 \%$ believe that voluntary experience can be better for work than paid employment (Source: Rook (2016, page 56). Rook reports that Internships have become popular in recent years. The Cambridge Dictionaries Online defines internship as 'periods of time during which someone works for a company or organisation in order to get experience of a particular type of work' (Source: Rook (2016, page 72). Internships enhance qualifications and existing experiences. They range in duration from two weeks to a year, and include some professional instruction and reflection. It is suggested that this training aspect makes this approach highly 
valuable to both applicants and employers. Internships only add value if used wisely, for example, by ensuring that valuable experience and feedback are provided. In contrast, Rook considers that so-called 'sandwich placements' are highly rated and appear to provide opportunities to advance existing qualifications and experiences in a number of ways such as undertaking substantial experience, developing excellent technical and transferable skills and making influential contacts. A further potential advantage is that the provision of some pre-placement training will assist job seekers finding a suitable position and completing relevant job applications. A formal reflection of people's personal development during and after time at work will further build on achieved qualifications and gained work experiences.

\subsection{Main Research Questions}

The main research questions for this research are:

1. What is meant by practical knowledge and experience? What is meant by qualifications and certificates?

2. What types of knowledge exist?

3. Are qualifications of higher value than practical knowledge and experience?

4. How can practical knowledge and experience and formal qualifications be brought together much more closely to create 'win-win' situations?

5. What will be the impact this could have on effective recruitment?

\section{Research Methodology}

\subsection{Method}

It is important in research to defend the methods the researchers chose to conduct this research. The primary reason for this in the current research is to demonstrate that both academics and practitioners can have confidence that the researchers have produced data that is true to its context. The main purpose of this section is to prove that the researchers are reliable and confident instruments for the collection, analysis and interpretation of the associated research data, through personal experience and by being immersed in its context. The researchers gained the trust of the participants in the face to face interviews, by applying a semi-structured and consistent approach to elicit empirical data to answer the main research questions. To fulfil the considered research aims and purpose of this study and to make a valid and reliable contribution to knowledge that is of value to both academics and practitioners, the researchers considered that a constructivist interpretivist approach within a phenomenological research paradigm was most appropriate for this research (whether a gap still exists between theoretical and practical applications in areas such as education, recruitment and employability). It is suggested that the change in working environments and working practices is the likely reason why this gap needs to be reduced or closed now. The researchers consider that the phenomenological approach is more suitable as the researchers are interested in understanding why something is happening rather than being able to describe what is happening. Meaning, in the context of this research, is more important to the 
researchers than measurement. The researchers hold the ontological view, in this context, that the world is socially constructed, including education, recruitment and employability and the people who operate within these, and that this world can only be understood by examining, for example, the perceptions of the human actors within it.

Face to face interviews formed an important part of this investigation to bring theory (literature review) and practice (face to face interviews) closer together and to answer the main research questions from Section 1.3. Table 5 is a summary of the questions asked during the face to face meetings with the research participants. All answers were recorded in writing or electronically where possible. Students provided their full approval and agreed that their first names could be used. 21 undergraduate students from the Universidad José Eduardo Dos Santos, Escola Superior Polítecnica do Bié, Angola, were interviewed over a three months' period in the third quarter of 2019. Of these 9 were female (43\%) and 12 were male $(57 \%)$. Their age ranged from 20 to 38 years. The average age was 25 years. All were undergraduate Second Year Psychology students. All students had extensive theoretical and practical experience in associated areas such as what is meant by knowledge, experience and qualifications and how these relate to, for example, job applications and career developments. They provided valuable insights for this research.

Table 5. Research Questionnaire for the Face to Face Interviews

1. What is the value of holding qualifications/certificates? What is the value of having practical experience? Discuss.

2. What is more important-theoretical knowledge or practical experience? Give examples.

3. What are the advantages and disadvantages of qualifications/certificates and practical experiences? Give examples.

4. Who would you employ-someone with just qualifications/certificates or someone with just experience? Discuss.

5. How could educational and practical experience and knowledge be brought together more closely? Be as radical and innovative as you can be.

\subsection{Data Collection and Interpretation}

The researchers, based on a similar recent research approach, considered two methods to collect relevant research data to answer the main research questions from Section 1.3: a review of the literature (Section 1.2) and face to face interviews (Section 3), within the context of a phenomenological research paradigm and an associated constructivist interpretivist research approach. The outcome of each research method such as literature review and face to face interviews increased the contributions made to answer the research questions from Section 1.3. The researchers consider that by employing more than a single research approach (when the same phenomenon is studied) such as literature review and face to face interviews, this has the advantage to validate that the contributions and validity of the research data are consistent and coherent. One of the researchers considers that he has made 
some contribution to the validation of the data from the face to face meetings. He participated in this research as a participant observer, thus being able to apply his extensive personal knowledge and experience in the subject matter under investigation to reduce the likelihood of the different methods actually producing different results. It was therefore possible to counterbalance strengths from one to another, and to build on the outcomes of the literature review. The data from the face to face interviews will test the conclusions that the researchers have drawn from the literature review by testing the theory from the literature review against this new data, drawn from contemporary practice. The findings from each of the research methods such as literature review and face to face interviews were based on an evidential analysis and interpretation of all collected research data. This was enriched by the contemporary view contributions from the interviewees and allowed for a balanced view to be presented. All interviews were conducted in a consistent and methodical manner. The result was a high level of data reliability and validity. Table 6 (Section 3) is a summary of the application and ranking of the examined theoretical knowledge and practical application skills set.

\section{Results}

\subsection{Face to Face Interviews}

What is the value of holding qualifications/certificates? What is the value of having practical experience? Discuss. 'Theoretical certification helps me to develop a much better understanding of the practical value of knowledge. Practical experience is very important to me, too, as I will be able to combine theory and practice to achieve optimum quality outcomes' (Nelson; Manuela; Celestina). 'From an evaluation point of view, certificates/qualifications give me the basis on which I can build a kind of 'scientific onboarding' as far as my later professional life is concerned. Practical experience helps to make any knowledge more believable' (Geronimo; Eugenio; Maria). 'The true value of theoretical certification lies in its inherent qualities to provide the foundation for all empirical and practical knowledge. It facilitates learning processes that are essential for combining theory and practice' (Jacisa; Augusto). 'For me, it is about linking acquired experiences to the taught theory to achieve optimum outputs' (Andre; Esmeralda; Lelia; Emilson). What is more important-theoretical knowledge or practical experience? Give examples. 'Previous theoretical knowledge for me is of equal importance to practical applications. One follows the other-we can have scientific knowledge but if we do not practise it, we lose it 'for real life' for good' (Florentine; Argentina; Anastacia; Valentine; Azevedo; Andreza). 'For me, practical experience is more important than theoretical knowledge. For example, in construction, I need to develop solutions that work in a given situation, or in a hospital when practical application cures a patient, and not so much the theory' (Horacio; Esmeraldo; Carlos).

What are the advantages and disadvantages of qualifications/certificates and practical experiences? Give examples. 'A formal well-studied qualification/certificate provides detailed scientific knowledge that will underpin any required practical applications later in working life' (Florentine; Jacira; Carlos). 'It appears to me that certain 


\section{Macrothink

qualifications/certificates are of particular value only in areas such as education and academia whereas both theory and practice are of value in most real-life work situations' (Nelson). 'In my opinion, the advantage of certificates is that it allows for the formation of a hypothesis that can be put to practice to test its validity and reliability. The disadvantage of certification is its asymmetry in the gender studies' (Geronimo; Eugenio). 'Many practices do not have a solid theoretical base and this often puts practice at a disadvantage over theory' (Andre; Manuela; Esmeralda; Horacio; Celestina). 'Many theories do not have a solid practical base, such as just learning the theory of driving but then ending up with driving a car dangerously' (Augusto; Maria; Horacio). 'A distinct disadvantage of not having formal qualifications/certificates is that it is not possible to apply for specific jobs, for example, in Angola' (Lelia). Who would you employ-someone with just qualifications/certificates or someone with just experience? Discuss. 'I would employ both. They can complement each other: the one with theory only can help the practitioner with theoretical insights, and vice versa' (Florentine; Nelson; Esmeralda; Horacio; Andreza). ' I would just hire those who have professional qualifications. Most institutions in Angola prefer formal qualifications' (Geronimo). 'I would try to hire practitioners who already have practical knowledge and experience in the chosen field. This would be of greater benefit to the institution, too' (Eugenio; Augusto; Maria; Emilson). How could educational and practical experience and knowledge be brought together more closely? Be as radical and innovative as you can be. 'We need to accept that theory is important, give it more credence, and then provide more possibilities for its practical application in real life work situations. Theory is not a panacea for success but it provides a solid foundation that should be of valid interest to practice' (Florentine; Geronimo; Esmeralda; Azevedo). 'Uniting the theoretical knowledge and the practical experiences is a very powerful combination. These walk hand in hand in a gradual and interdependent process, and can provide solutions to the social problems that exist in our society' (Jacira; Andre; Augusto; Esmeralda; Lelia; Carlos). 'Adopting both theory and practice as a single unit can be very satisfactory for individuals as well as the society people live in, with particular emphasis on understanding their practical effects in different social contexts' (Maria; Horacio; Emison). 
Table 6. Application and Ranking of the examined theoretical knowledge and practical application skills set

\begin{tabular}{|c|c|c|}
\hline Skills Set & Application & Ranking \\
\hline $\begin{array}{l}\text { Blend of theoretical Knowledge } \\
\text { and Practical Application }\end{array}$ & $\begin{array}{l}\text { To aid a smoother transition from education to } \\
\text { full-time employment }\end{array}$ & $\begin{array}{l}\text { Identified by all parties } \\
\text { as being important } *\end{array}$ \\
\hline Workplace Experience & $\begin{array}{l}\text { To develop important work-related knowledge and } \\
\text { experience }\end{array}$ & $\begin{array}{l}\text { Identified by all parties } \\
\text { as being important } *\end{array}$ \\
\hline New Subject Areas & $\begin{array}{l}\text { To apply higher levels of choice and flexibility and } \\
\text { to acquire new knowledge and recognized } \\
\text { qualifications/certificates }\end{array}$ & $\begin{array}{l}\text { Considered important by } \\
\text { the Literature Review }\end{array}$ \\
\hline Apprenticeship & To bring theory and practice much closer together & $\begin{array}{l}\text { Considered important by } \\
\text { the Literature Review }\end{array}$ \\
\hline $\begin{array}{l}\text { Attitude, Behavior and Personal } \\
\text { Qualities }\end{array}$ & $\begin{array}{l}\text { To develop the personal attributes people and as } \\
\text { such their professionalism }\end{array}$ & $\begin{array}{l}\text { Considered important by } \\
\text { the literature review. }\end{array}$ \\
\hline Learned Skills Set & To apply in real life work environments & $\begin{array}{l}\text { Identified by all parties } \\
\text { as being important } *\end{array}$ \\
\hline Right level of Qualifications & $\begin{array}{l}\text { To ensure that qualifications match requirements } \\
\text { such as jobs (to avoid overqualification) }\end{array}$ & $\begin{array}{l}\text { Identified by all parties } \\
\text { as being important } *\end{array}$ \\
\hline Networking & $\begin{array}{l}\text { To develop networking capabilities to sustain } \\
\text { career prospects }\end{array}$ & $\begin{array}{l}\text { Considered important by } \\
\text { the Literature Review }\end{array}$ \\
\hline Transferable Skills & To develop people's mindsets & $\begin{array}{l}\text { Considered important by } \\
\text { the Literature Review }\end{array}$ \\
\hline
\end{tabular}

*Literature review and face to face interviews

\section{Discussion}

It appears, and perhaps does not come as a surprise, that qualifications only a few years ago, became the de facto standard, for example, for obtaining a good job. Increasing education costs and suggestions from the community of practice suggest that nowadays work experience has overtaken qualifications as the preferred attribute for employers. This raises an interesting question: Do qualifications still provide an optimum indication of who is the most suitable candidate for a job, or has this been replaced by practical knowledge/experience? The outcome from this research revealed two opposing views: qualifications are more important and the value of experience at work is of paramount importance. The first school of thought suggests that a qualification such as a university degree is not primarily concerned with getting a job or starting a work career. Associated benefits include intellectual, personal and social capacities and abilities. The job market appears to be driven by and focused on people's intellect/brain rather than people's manual and practical skills. Some scholarly authors express views that there is a need for both academic and experience-based skills. They argue that, for example, theory demonstrates that something does not work but that, when this is combined with practice, it is possible to provide valid and reliable reasons why something does not work. Although practice and experience provide a plethora of new ideas, 
processes and new ways of thinking/learning, it is argued that educated people are able to learn much faster, and in more depth, compared to those who do not hold qualifications/certificates. These views are supported by evidence from the literature review that people who, for example, study for two years (theory) and who are then placed for a year within the industry, are more likely to have a successful career in front of them, though their ability to combine the best from both theory and practice. The second school of thought is mainly focused on knowledge and experience gained from actual work experience (practice). Someone who, for example, has completed three years of practical work experience by the time they are 21 years old, would have gained substantial advantages over their student counterparts. Employers value practical knowledge and experience much more than just theoretical knowledge and experience, and are, therefore, more likely to hire experienced candidates. It appears that the number of people who hold a formal qualification such as a degree, has risen steadily over the last few years. As a result, employers are more focused on experience rather than qualification. It is not simply a question of 'supply and demand'. It is more associated with who is the best fit for the company, with particular emphasis on the speed of settling into the new organisation, being able to hit the ground running and keeping actual recruitment costs down due to candidates becoming effective in their new roles much faster. It appears that many employers list a degree as desirable and that they review the experience of potential candidates first, followed by education, except in certain industries such as law and accountancy, where certain education levels are a necessary requirement. Both theory and practice appear to be highly desirable, irrespective of which school of thought is considered or followed. There are many successful people with and without degrees or other formal qualifications who are highly effective in their jobs. Based on the outcome of the literature review and the face to face interviews, it appears that a good combination of theoretical knowledge and practical understanding (Fig. 4) has the potential to reduce the identified gap of this research in the areas of education, recruitment and employability.

Theory

Practice

Knowledge/Experience

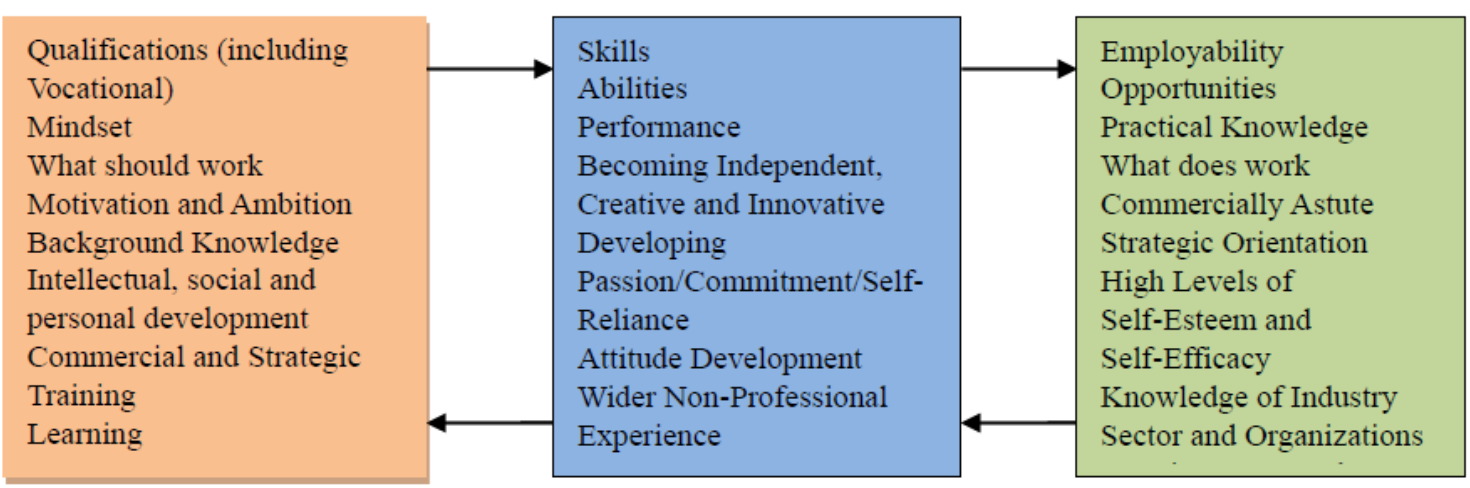

Figure 4. The Practical Knowledge v Qualification Challenge, adapted from Nicholls (2005) 


\section{Conclusions}

Based on the strength of the evidence from both the literature review and the face to face interviews of research participants, the researchers conclude that the identified gap exists and that there is a potential need to develop appropriate solutions and recommendations for their application in the areas of education, recruitment and employability. The researchers consider that there are a number of (there may be more) potential, relevant and achievable approaches that could reduce the identified gap, for example, putting the main focus on practical knowledge and experience and creating the right conditions for providing associated theoretical training that will strengthen the practical know-how. Learning environment and learning spaces such as vocational courses, distance learning, web training and day/evening classes at appropriate educational institutes are available for adoption. In contrast, putting theory first, supported by practice, is another considered option. For example, recruit people with theoretical knowledge and prioritise their personal development by focusing, during the first six months, on improving/developing people's practical knowledge and experience. Another option is to re-design Ordinary and Advanced Level educational courses and include practical application training such as practical workshops where theory can be put into practice in safe laboratory-type environments. In addition, greater emphasis should be placed on practical work experiences such as short-term placements with companies across the industries. And finally, a hybrid approach that focuses on adopting best principles and elements of both theory and practice that will enrich learning with personal practical experiences, both positive and negative, to provide some balance between theory and practice. The hybrid approach appears to be most appropriate as it provides a good balance between theory and practice. It should be of particular interest to companies who wish to reduce their recruitment/staff replacement costs (Section 1.2) through the adoption of a balanced theory/practice recruitment approach. This research was limited to inputs from a number of undergraduate students from Nigeria. The researchers suggest that it would have been beneficial to obtain inputs from more practitioners and theorists from across the industries to shed further light on how the identified research gap could be filled or reduced. Further research is suggested to develop a new model for bringing together education, recruitment and employability to optimise value-adding insights. The researchers acknowledge that the recommended solutions by this research may need to be adapted to suit particular local, cultural, industry or country specific idiosyncrasies. The research questions (Section 1.3) have been answered.

\section{Acknowledgements}

The corresponding author wishes to thank the Universidad José Eduardo Dos Santos, Escola Superior Polítecnica do Bié, Angola for providing access to interview students from the Faculty of Psychology/Social Psychology outside of formal teaching hours to assist with the completion of this research.

\section{References}

Becker, L., \& Becker, F. (2016). Seven Steps to a Successful Career (Student Success), Sage Study Skills. 


\section{Macrothink}

Business and Economic Research ISSN 2162-4860 2020, Vol. 10, No. 1

British Qualifications (2019). A Complete Guide to Professional. Vocational and Academic Qualifications in the United Kingdom, 49, Kogan Page.

Dacre, P. L., \& Sewell, P. (2007). The key to employability: developing a practical model of graduate employability, Education and Training, 49(4), 277-289.

https://doi.org/10.1108/00400910710754435

Garcia-Mainar, I., \& Montuenga, V. (2019). The signalling role of over-education and qualifications mismatch, Journal of Policy Modeling, 41(1), 99-119.

https://doi.org/10.1016/j.jpolmod.2019.02.015

Hillage, J., \& Pollard, E. (1998). Employability: Developing a framework for policy. Research Report RR85, Department for Education and Employment.

Kolb, D. A. (1984). Experiential Learning: Experience as the Source of Learning and Development. New Jersey: Prentice-Hall.

Koval, S. B., Isakova, E. S., \& Chistyakova, E. V. (2016). SUSA Universal Method for Assessing Employer Satisfaction with the Student and Graduate Qualifications Quality, Procedia Engineering, 150, 2102-2107. https://doi.org/10.1016/j.proeng.2016.07.245

Lumley, M., \& Wilkinson, J. (2014). Developing Employability For Business. Oxford University Press.

McGuinness, S., \& Sloane, P. (2011). Labour market mismatch among UK graduates: An analysis using REFLEX data, Economics of Education Review, 30(1), 130-145.

https://doi.org/10.1016/j.econedurev.2010.07.006

Miller, A.; Watts, A. G., \& Jamieson, I. (1991). Rethinking work experience. The Falmer Press, and Chapter 1: Jamieson, I. and Miller, A., 3-15, and Chapter 2: Watts, A. G., 16-38.

Nicholls, G. (2005). New lecturers' constructions of learning, teaching and research in higher education. Studies in Higher Education, 30(5), 611-625.

https://doi.org/10.1080/03075070500249328

OECD (2000). From Initial Education to Working Life-Making Transitions Work: Education And Skills, $O E C D$.

Rook, S. (2013). The Graduate Career Guidebook, Palgrave MacMillan.

https://doi.org/10.1057/978-0-230-39174-1

Rook, S. (2016). Work Experience, Placements \& Internships, Palgrave Macmillan Education. https://doi.org/10.1007/978-1-137-46202-2

Sewell, P., \& Dacre, P. L. (2010). Moving from conceptual ambiguity to operational clarity. Employability, enterprise and entrepreneurship in higher education, Education and Training, 52(1), 89-94. https://doi.org/10.1108/00400911011017708

The Concise Oxford Dictionary (2011), Oxford University Press, United Kingdom.

Trought, F. (2012). Employability Skills, Brilliant Graduate Career guides, Pearson Education 
Ltd.

Williams, L. (2018). Ultimate Job Search, 5, Kogan Page.

Woodman, P., \& Hutchings, P. (2011). Tomorrow's Leaders, CMI, London.

www.aspirepersonnelltd.co.uk

www.dictionary.cambridge.org

www.totaljobs.com

www.ucas.com

Yorke, M. (2006). Employability in higher Education: what it is -what it is not. York: The Higher Education Academy. [Online] Available:

https://www.heacademy.ac.uk/assets/documents/tla/employability/id116-_employability_in_ higher-education_336.pdf

\section{Copyright Disclaimer}

Copyright for this article is retained by the author(s), with first publication rights granted to the journal.

This is an open-access article distributed under the terms and conditions of the Creative license (http://creativecommons.org/licenses/by/3.0/).1 